\title{
The Barriers and Challenges Faced by Private Sector Higher Education Institutions (HEIs) in Promoting Sustainable Development: A Qualitative Inquiry in Pakistan
}

\author{
Muhammad Waqas* \\ Muqaddas Rehman ${ }^{* *}$ \\ Abdul Rehman ${ }^{* * *}$
}

\begin{abstract}
Private sector higher education institutions (HEIs) play a significant role in advancement of sustainability. In Pakistan still this concept is in stage of infancy and has received little research attention. Moreover, HEIs in private sector are facing a lot of barriers and challenges in its implementation. In this backdrop, the purpose of this exploratory study is to determine the roles, barriers and challenges for development of sustainable private sector HEIs in Punjab using semi-structured interviews form 11 faculty members working in private sector HEIs in Punjab, thematic analysis was carried out using NVivo 12. In general, all the participants agreed that private sector HEIs are the knowledge creating institutes and they can actively promote the sustainable development in Pakistan through faculty training and active involvement of all the stakeholders and action oriented research. Major barriers were found to be lack of finance, poor research culture, faculty incompetency and inadequate management support. It is suggested that HEIs must use the resources in an optimal manner and develop appropriate class room environment, effective curriculum, right technology usage, solution based research and well developed infrastructure to generate the innovative solutions for sustainable development.
\end{abstract}

Keywords: HEIs, private sector, sustainable development, barriers, challenges

\footnotetext{
* Assistant Director (Accreditation), Punjab Higher Education Commission, Email: waqas_epouch@yahoo.com

** Associate Professor, Hailey College of Commerce, Email: muqqadas.rehman@superior.edu.pk

${ }^{* * *}$ Professor/Chairman, Superior University, Lahore, Email: ceo@superior.edu.pk
} 


\section{Introduction}

Sustainable development is integrating into the curriculum at all education levels needed to ensure that students from primary to postsecondary are aware of its imperatives and respect its principles and values in their professions and as habits of everyday life, that required the incorporation of concepts of sustainability into educational curriculum (Ubuntu Declaration, 2002). Since the discussion of role of educational institutes in promotion of sustainable development in United Nations conference for Environment and Development, the HEIs all over the world have become more vigilant regarding this agenda. Additionally, the role of HEIs in development of sustainability was also reaffirmed by the Nagoya Declaration in 2014. During the World Conference on Education for Sustainable Development held on 10 to 12 November 2014 in Aichi-Nagoya, Japan conducted by United Nations Educational, Scientific and Cultural Organization (UNESCO) all the participants decided for urgent action to further strengthen and scale up Education for Sustainable Development (ESD), in order to enable current generations to meet their needs while allowing future generations to meet their own with a balanced and integrated approach regarding the economic, social \& environmental dimensions of sustainable development.

Declarations of Education for Sustainable Development (ESD) has gained significant attention but yet there is lack of academic research focus. Sustainable development means meeting the needs of present society without having to compromise the needs of future generation. The higher education institutions can play their vital role through rearrangement of societal, budgetary and educational objectives (Velazquez, Munguia \& Sanchez, 2005). HEIs can lead by example and bring about transformational change in life styles, promote sustainable practices and take society towards a sustainable future (Amaral, Martins \& Gouveia, 2015).

Wright (2006) argued that HEIs are leading institutions that have the ability to play an important role in developing a better understanding of complex issues related to society and environment. They have also the capacity to create solutions to main sustainability for future generations. In similar line, it has been claimed by researchers that it is the ethical obligation of HEIs to contribute with the leading role in educating the society and decision makers regarding sustainability (Clugston \& Caldar, 1999). This has introduced the concept of sustainable higher educational institutes (SHEIs), that promote sustainable development on economic, 
societal and environmental level by optimal utilization of resources in carrying out its functions of research, partnership, teaching and stewardship (Jorge, Madueño, Cejas\& Peña, 2015). Such sustainable universities promote a sustainable way of living in society by taking in view its infrastructure, knowledge transfer, participation of stakeholders, efficiency in using energy and resources embodied in its strategic actions (Wright \& Horst, 2013). They further added that sustainable development of Canadian universities/colleges faculty leaders occurred due to their own understandings, education, daily operations and research. They further defined that financial, leadership incentive and demand are the major barriers to sustainability of universities.

Pakistan that is ranked as a developing nation has lagged far behind in the attaining the goals of sustainability, where people and institutions are still un-aware of this concept and its importance (Zahid, 2018). Pakistan is facing sustainability issues in terms of economic, societal and environmental contexts. Due to climatic change, poverty and educational crisis, Pakistan is facing many issues regarding sustainable development (Qadir, 2016). Jegede (2016) indicated that in the developing nations the private sector HEIs are increasing in number and becoming an influential institutional sector that imparts them even more responsibility of contributing in sustainable development initiatives.

There are twenty four private sector HEIs which have been chartered by Government of the Punjab. The ratio of private sector HEIs is growing day by day but they are lacking focus on the issues of sustainable development. The stakeholders in HEIs include the university leadership, teaching faculty, administrative staff, students and external bodies (Wright\& Wilton 2012), that can play a collaborative role in making Pakistan a sustainable nation. Despite the fact that sustainability in HEIs has been looked into for more than twenty years but little attention has been given in promoting the sustainability of HEIs in Pakistan (Mughal, Qaisrani, Solangi, \& Faiz, 2011). It has been identified by Wright (2006) that there is still a gap in understanding of the concepts of sustainability and sustainable development among the stakeholders in HEIs. There is lack of consensus on the part HEIs can play in sustainable development all over the world and Pakistan is no exception (Zahid, 2018).

This research area is neglected in Pakistan and calls for examining the role of HEIs in reinforcement of sustainable development along with the identification of potential barriers and challenges. Tapia-Fonllem, Fraijo-Sing, Corral-Verdugo \& Ortiz Valdez (2017) called for carrying 
out qualitative inquiry from the stakeholders to gain their deeper perspective into the role of private sector HEIs for supporting initiatives of sustainability.

The objective of this research is twofold; first it contributes to the literature in area of sustainable development and role of HEIs in its promotion by offering a comprehensive conceptual framework. Secondly, it gives practical suggestions to make the higher education as a significant supporter of society's undertakings to achieve sustainability. In this backdrop, this research offers answer to the following research questions:

1. How sustainability is perceived by the stakeholders in private sector HEIs?

2. What role of private sector HEIs can play in sustainable development in Pakistan?

3. What are the major barriers and challenges that private sector HEIs are facing in developing a sustainable society?

\section{Theoretical Framework}

\section{Sustainability and Sustainable Development}

Lozano (2008) offered an extensive definition of sustainability, it refers to meeting the requirements of present without bargaining the capacity of future generations to fulfil their needs. The concept of sustainable development refers to an idea that in modern society the link in economic development, people and planet cannot be separated, In quest of wealth generation the ecosystem and societal demands should not be compromised. The expansion of cities and the post industrialization era is witnessing the issues of pollution, soil degradation and resource depletion. Thus, sustainable development is having economic progression without effecting environment, society and people's wellbeing (Dempsey, Bramley, Power\& Brown, 2011).

\section{Sustainable Higher Educational Institutions (SHEIs) and Role of private sector HEIs}

Many researchers have already explained that HEIs play a substantial role in promotion of sustainable development (Amaral et al., 2015; Godemann, Bebbington, Herzig\& Moon, 2014). Stephens et al. (2008) recommended that HEIs can accelerate societal transition 
and catalyst in achieving sustainability. Sustainable HEIs promote societal, economic and environmental preservation by optimal use of resources at regional as well as international level. To participate in the goal of attaining sustainable development HEIs increase focus on research culture, partnership and outreach to overcome problems of society and participate in betterment of life styles of the people. HEIs play their leading roles in overall sustainable development. Such institutions are well aware of the concepts of sustainable development and take concrete steps in order to promote and achieve sustainability (Milutinovi \& Nikoli, 2014).

There are twenty four private sector universities /institutes which have been awarded charter by Government of the Punjab. Jegede (2016) indicated that the private sector HEIs are increasing in number in developing nations making them an influential institutional sector, that imparts them even more responsibility of contributing in sustainable development initiatives. Adams (2013) elaborated following points for HEIs to ensure sustainable development (a) involvement of staff and students (b) clear communication (c) positive leadership (d) action based research (f) any other activity which can enhance sustainability. Barth (2013) stated that culture can also drive the process of sustainability based multidisciplinary research, leadership and supportive system.

\section{Barriers to Sustainability in HEIs}

There are obstructions that influence activities cultivating sustainability in HEIs, the most important of which is the nonawareness of this concept. For the stakeholders in HEIs, much complexity and ambiguity is involved to the real sustainability idea, which is considered as a dynamic and complex theme (Shriberg \& Harris, 2012; Wright\& Horst, 2013) .The lack of awareness regarding this concept promotes absence of interest and involvement of faculty, management, students and policy makers in sustainable development initiatives (Weber \& Duderstadt, 2012; Verhulst \& Lambrechts, 2012). Top management in the HEIs also lacks active engagement in establishment of sustainability development programs (Adams, 2013; Milutinovi \& Nikoli, 2014; Jorge et al., 2015).

Second, the absence of financial resources and sponsoring has emerged to be another barrier in impeding HEIs to play their part in sustainable development (Waas, Hugé, Verbruggen \& Wright, 2012; Shriberg \& Harris, 2012). Due to shortage of finance most of the 
universities consider the programs of sustainable development as an extra expense and thereby they do not pay attention toward their formation and implementation (Velazquez et al., 2005).

Third, people fear the change linked with the development and implementation of sustainable exercises that proves to be another barrier (Adams, 2013). Fourth, inflexible, traditional, conservative and conventional cultures prevailing in HEIs bars them from the adoptions of new concepts and ideas such as sustainable development; because these cultures are not open to new ways of thinking (Weber \& Duderstadt, 2012; Verhulst \& Lambrechts, 2015). They have inefficient correspondence and sharing of data across vertical and horizontal levels. They have focus just on immediate profit earning and they consider the programs of sustainable development as an extra financial burden (Verhulst \& Lambrechts, 2015).

Fifth, due to absence of specialization and training in sustainability, most of faculty members, policy makers, leaders and administrative tafflack knowledge of sustainability (Velazquez et al., 2005). Pakistani private sector HEIs are also facing same above mentioned barriers regarding lack of infrastructure and trained staff and shortage of $\mathrm{PhD}$ teaching faculty in the private sector HEIs. Punjab is the most populous and second largest province of Pakistan (Sabir, 2008).

\section{Challenges faced by HEIs in Sustainable Development}

Financial issues act not only as barrier but also as a challenge for implementing the sustainable development program in HEIs (Elliott \& Wright, 2013).

Verhulst and Lambrechts (2015) explained that availability of financial resources can foster the sustainability, but having enough finance to support the initiatives of sustainable development proves to be challenges. Further, focused that sustainability may be driven by external and internal forces, external financing, and commitment of each stakeholder and evaluation of present sustainability. Davis et al. (2009) pointed out that having right infrastructure and supportive environment are among prime challenges of sustainable development. Mader, Scott\& Abdul Razak (2013) mentioned that having right governance and active collaboration and engagement of management in sustainable development is also a challenging task. 
The methods of sustainability can be implemented through involvement of stakeholders. The major challenge for sustainability gaining involvement of all the participants in HEIs. Attaining engagement of leaders (directors, president and rectors), students, faculty (professors and researchers) and external stakeholders (regional and local level) proves to be yet another ordeal (Godemann et al., 2014; Verhulst \& Lambrechts, 2015).

\section{Perceptions of key HEI stakeholders}

Sammaliset al. (2015) focused on the significance of perceptions of stakeholders in sustainable development in HEIs. Filho (2011) explained that behaviours of key stakeholders play a vital role in sustainability of HEIs. Collaboration of key stakeholders is essential for sustainable development efforts (Stephens, Hernandez, Román, Graham, \& Scholz, 2008).

In development of sustainability, literature shows that leadership play main role that is decisive in nature (Clugston \& Calder, 1999; Wright\& Horst, 2013). In addition, the teaching faculty's perceptions regarding sustainability and its impact on societies and environment can bring about change in organization it may help teaching faculty in day to day routine matters that help in implementation of sustainability (Christie, Miller, Cooke\& White, 2015; Grindsted, 2011). For implementation of sustainable strategies the administrative staff must be trained in all the HEIs which should be familiar with the concepts, terminologies, institution strategies for implementation of sustainability particularly familiarity of technology use and rewards for conservation of energy. The students are major key stakeholders to drive the sustainability by carrying out actionable research and active involvement in sustainability programs (Davis, O'Callaghan \& Knox, 2009; Zeegers \& Clark, 2014).

The focused role of HEIs in promotion of environmental issues and role of external stakeholders towards sustainability in the competitive environment carries paramount importance (Figueredo \& Tsarenko, 2013). External stakeholders (regional/local) as prescribed by Waas et al. (2010), include customers, research partners, government agencies and providers of university services should add to the transition to a sustainable world. 


\section{Methodology}

\section{Research Design}

This is a qualitative exploratory study that is aimed at exploring the insights of respondents (Bryman, 2016). The researcher has adopted phenomenological design in which the lived experiences of respondents were observed. It explains how a specific phenomenon is experienced by human beings (Punch, 2013). It is a suitable method as it allows the exploration of barriers and challenges of sustainability experienced by the staff of private sector HEIs.

\section{Research Instrument}

In order to collect the research data semi-structured interviews were conducted (Bryman, 2016). The research questions are adapted from the existing research in sustainable HEIs (Wright \& Wilton, 2012; Wright \& Horst, 2013; Elliott \& Wright, 2013) in the context of Pakistani environment( See appendix A).

\section{Validity and Reliability}

To make sure the data is valid and reliable external coders were invited that coded the data and developed themes independently which were matched with the codes and themes that developed by the researches and removed disparities (Silverman, 2013). Furthermore, the concept of participant verification was employed to make sure that reporting is valid (Punch, 2013). The interpretation of themes was sent to participants via email and they were asked to validate their credibility.

\section{Sample and Procedures}

There are twenty four private sector HEIs which are operating in the Punjab province and have been given charter by Government of the Punjab. A purposive sampling technique is used, data is gathered from four private sector HEIs i.e. Minhaj University, Lahore, Global Institute, Lahore, University of Lahore and Hajvery University, Lahore. Eleven respondents were face to face interviewed. This sample size is adequate as Sandelowski (1995) indicated that minimum sample size of ten participants should be chosen for having in-depth insights. 
Furthermore, it is also appropriate according to the criteria of 1-30 respondents proposed by (Fridlund \& Hildingh,2000). The participants are faculty members and their profile is availableat Appendix B. Teachers are the stakeholders that are in touch with students, administration and parents so they were considered most suitable source of gathering data. All the interviews were audio recorded and then transcribed on the basis of audio voice.

\section{Data Collection and Content Analysis}

The responses were assembled through semi-structured interviews and analysed using NVivo 12 through thematic analysis technique (Braun\& Clarke, 2006), grasping both a deductive and inductive code procedure (Saldana, 2009). First of all the data was transcribed and familiarization with data was obtained. The codes were created form the interview transcripts and previous literature. The codes were converted into themes and the themes were subsequently reviewed and refined. The following steps were followed in the analysis through NVivo.

- A new project file was created

- The interview files were imported in the software

- Cases were created in name of each participant

- Nodes were developed for all the themes

- The pertinent part of interview was coded to the relevant node theme and the process was completed for 11 interviews and all themes

- Matrix coding query was run to find the link in participants responses and the frequency of theme reporting (graph was created for the same).

- The conceptual map was developed

\section{Interpretation and Discussion}

\section{Sustainable Development}

The participants expressed different kind of views regarding the concept of sustainability. The faculty members expressed it as being about keeping in view the future needs, effective resource usage, protection of resources for the next generation and efficiently managing the existing resources. These views are relevant to (Lozano, 2008). 
As indicated by the following participants "Without natural resources you have to sustain but without natural resources you cannot deplete" (Faculty member 1).

One of the participant indicated that he recently came to know about this idea

"I came to know about sustainable development almost two and half years before and it is long term improvement without any stop or continuous. It is not on the cost of future generation, it means resource of future generation should not be used by the current generation"(Faculty member 7).

Another stated that he came to know about it through a seminar:

"I heard this term during a seminar on Water Day for protecting natural sources held in our university. In sustainable development, there is a need to rely and manage the existing resources without any dependence or compromising upon the resources of the future generations" (Faculty member 10).

\section{Sustainable Institution}

In contrast to the responses about sustainable development some of the faculty members had no idea about the concept of sustainable institution as already mentioned by (Koscielniak, 2014; Velazquez et al., 2005), such as:

"I have never heard the term sustainable institution before this but hear the term sustainable development. Means keeping in mind standards, levels, benchmarks and thresholds on the basis of which private sector higher education institutions perform their functions to run in the market. "(Faculty member 3 ).

Another member said, "I never hear the term sustainable institution and this is new term for me" (Faculty member 7).

It shows that still there is lack of knowledge regarding the concept of sustainable institutions in Pakistan.

While some of the participants were well aware of the concept as they said that sustainable institutions are those that play an active role in efficient resource usage, knowledge generation and education regarding the sustainable development to conserve the resources for future. 
"It means that how resources are effectively using by the institutions as the sustainable institution is new term for me while I am familiar about sustainable development" (Faculty member 4).

"Sustainable institution is very much concerned with sustainable development because if the development is sustainable then the institution is sustainable. The development provides basis for the sustainable institution" (Faculty member 11).

The institutions have an active plan to improve the sustainability in the area of health, food and climate conservation. As one of the member said, "Sustainable institutions develop plan for the long-term programs for improving health, taking steps for better climate, improving the quality of food, and keeping their culture" (Faculty member 10).

\section{Role of Private Sector HEIs}

This is regarding the role of private sector HEIs in promotion of sustainable development. This theme was sub-categorized in three subthemes. Wright \&Walton, (2012) and Wright \& Horst (2013) have already explained this concept in their studies.

In general, all the participants agreed that HEIs are the knowledge creating institutions and they can actively promote the sustainable development in Pakistan through faculty training and active involvement of all the stakeholders. This will allow the private HEIs to generate the innovative solutions for sustainable development. The role of institution is vital for generation of new knowledge and proving innovative solutions to the various problems of society and economy (Faculty member 2).

The resources must be used in an optimal manner and development of effective curriculum that teaches the students regarding sustainability: For achieving sustainable there should be optimal use of resources which includes financial, physical and academic resources means curriculum etc.(Faculty member 7).

Higher institutions are considered as mini towns, because mostly institutions have their own health care centers, sports centers, green environment centers, clean water plants, latest transport system, food areas, power plants, etc. Universities educate students; improve the well-being and health of individuals and communities through integrated programs of teaching, research and service. Hence, according to this perspective the institutions can play a major role in achieving the sustainability (Faculty member 10). 


\section{Infrastructure and Technology}

The right technology and infrastructure can allow the universities to play the role in sustainable development.

For sustainability our institution is prime to support infrastructure like enhancement in building for accommodation of students, class rooms and teacher's offices. We trying to get new technology like mass media, radio, TV and hopefully this institution will be able to launch own radio education channel that will be pure educational channel not entertainment channel (Faculty member 7).

Furthermore, the right class room environment, use of social and mass media, IT, training, use of modern technology, laboratories, and advanced research tools and equipments can also help in this process.

Beside routine studies, our institute provides state of the art laboratories to the students for developing semester and final year projects based on latest technology using modern tools and up to date hardware that builds a good environment (Faculty member 10).

But, lack of finance and management support in this regard was indicated by a few participants:

This is the problem of finances, if you have finances then you have better laboratories, library and facilities for the teachers, students, institution because this is world of competition and living with this competition there is need to work hard then you can do something (Faculty member 8).

This institution is not providing well infrastructure and technology as the owner of this institution has not academic vision while faculty is forcing him to adopt it. In another campus of this institution, we have good infrastructure and technology in every class room. This institution has up to the mark resources which can fulfil the demand of students (Faculty member 4).

\section{Research Culture}

In line with Lozano et al. (2013) who signifies the importance of practical research for sustainable development; this was indicated by the participants that the research must be action oriented, based on local issues, that focuses on the grass root level investigation and in this regard the public and private sector partnership could also be fruitful:

Without research there is not possible to have graduate programs, research should focus to deal the local problems on ground realities and graduates must be able to provide solutions to overcome those problems. 
Further, there must be public private partnerships to promote the research culture and there is need to diverge the attention in other cities to access the higher education (Faculty member 1).

Respondents think at present the quality of research is quite low due to less competent faculty and poor culture. As indicated by the participants, at present the research culture is less developed in private sector HEIs in Pakistan that requires more actionable and practical research to tackle the real world issues such as sustainable development:

One participant said, No, because the knowledge generation by the private section higher education institutions is not innovating as per need (Faulty member 2).

In Pakistan there is need of more actionable research which help the organization to solve the problems at gross root level while private sector higher education institutions are doing repetitive research that does not breed outcomes (Faculty member 3).

There should be a practical culture for research but unfortunately private sector institutions concern is with profit earning. These institutions are facing issues as they have not sources of funding from Higher Education Commission or Government (Faculty member 4).

\section{Stake Holders}

Faculty members, administrative staff, university leadership, students and external parties are among the major stakeholders in HEIs who play their role in sustainable development (Yarime, et al. 2012). In the similar line, four main stake holders were identified in the course of interviews i.e. administrative staff, faculty, students and university leadership. It was said, "Definitely, all the three stakeholders' faculty, administrative staff and students and ignoring of any of them will not produce the positive results" (Faculty member 9 ).

Loyalty, commitment and support from the faculty and the combined collaboration and cooperation by all the stakeholders are needed to develop sustainable HEIs.

Faculty is playing its role verywell, while administrative staff is supporting the faculty in promotion of sustainability of the institution. Students are also wants to play their role and faculty is supporting them in this regard (Faculty member 3 ).

Every stakeholder like faculty member, administrative and students have to play in promotion of the institution. If the faculty is very highly qualified then we will produce good students and they will reflect their 
ability in the future world so we have to work hard for this world (Faculty member 8).

All stakeholders provide guidance, cooperation and help regarding the promotion of sustainability except the industry and government (high unemployment ratio breaks the sustainability cycle) (Faculty member 10).

In case the stakeholders are not committed and they have low devotion, nothing can be attained.

In most of the private sector higher education institutions the faculty members and the administrative staff they keep on changing from one institution to another institution because they have not loyalty and commitment with their organization due to owing the job at stake and hireand fire system then you cannot show your devotion with the organization (Faculty member 2).

\section{Barriers}

A number of barriers were identified by the participants that are causing a hurdle in sustainable development promotion by private sector HEIs. These barriers are same in line with Sibbel (2009).

\section{Funding}

Lack of finance was indicated as one of the main barriers as it causes the universities to not have the required infrastructure and technologies that can be devoted to sustainable development. The crisis of funding can cause the sustainability in line with (Wright \& Horst, 2013).

Private sector institution must has sufficient funds, own infrastructure, trained qualified teaching faculty, written documents, reward \& punishment system (proper examination system) because these things are related to the future youth all these can prevent the private sector institution from engaging in sustainable enterprises(Faculty member 1)

The major barrier of private sector higher education institution is financial barrier because income of these institutions is only fee which they collect from students, if fee is less then they cannot work for development and technology is another barrier because most modern technology could not be attained without financial resources. Financial resources is main barrier for private sector higher education institutions because these institutions are not funded by the Government or from any other agency and they have to raise their funds from the enrolment of the students (Faculty member 7). 


\section{Cultural Background}

The students come from different backgrounds and they are mostly from backward areas and government institutes that are only interested in getting degree. They have no concern toward the research and knowledge creating activities.

The students from low background are the challenges for sustainable development of any private sector higher education institution because they are not ready to accept the challenges in their life and complete tasks like quizzes \& assignments. The development is halted and stopped by such kind of students because they just want to get degrees (Faculty member 3 ).

\section{Resistance to Change}

Most of the management is not ready to change and take the initiatives for sustainable development as one said, "The change in management is the resistance to take sustainable initiatives in the private sector higher education institutions (Faculty member 6).

\section{Owners Mind Set}

Most of the university owners are engaged in cost minimization and they do not like to invest in changing the culture for sustainable development.

The facilities provided by the administration of the institution are not up to mark which is required to fulfil needs. The finances are very limited in nature by the private sector higher education institutions which are another barrier which can prevent institutions from engaging sustainable initiatives. One more barrier is the mind set of owners of the institutions which are not ready to change the culture of the organization (Faculty member 3).

\section{Lack of Commitment}

The university ownership is also mostly concerned to the earning of profit. One of the participants said, With the lack of commitment by the owners of private sector higher education institutions is the barrier to prevent the institution from engaging in sustainable (Faulty member 2). 


\section{Low Salary Packages}

Universities do not pay adequately to the faculty members and in turn they are not motivated to engage in any positive extra-role behaviour.

Low salary packages and non-payment on timely to the faculty of this institution can prevent from engaging in sustainable initiative. To overcome this problem the institution must employed trained teaching faculty including $\mathrm{PhD}$ faculty members. Due to this trained faculty members moved to other institutions where they get better pay package and facilities for their survival (Faculty member 5).

\section{Training of Faculty}

The institutes are not having enough opportunities to train their faculty members on the issues of sustainable development.

Hiring of Trained and qualified faculty must be in accordance of criteria of Federal HEC and Provincial HEC. Infrastructure, finance and achievement of goals which have set by the Private Sector Higher Education Institution can be achieved through trained and qualified faculty. Further, visiting faculty is not the solution for sustainable development of Private Sector Higher Education Institutions. For grant of charters to the newly establishment institutions they must meet the criteria for sustainable development of Higher Education Institutions (Faculty member 1).

\section{Challenges}

\section{Modern Technology}

Most of the private sector institutes are facing the challenge to acquire modern technology and use it in an efficient way to ensure the sustainable development. These results are in line with Verhulst and Lambrechts (2015).

Technology adopting is the major issue of this institution. The world is moving rapidly while this institution is lack of using technology advancement and there is difficult to survive in the highly competitive environment (Faculty member 4).

The change in new technology is the main barrier which may cause heavy cost as the world is changing now a day's rapidly. If any institution will not adopt the changing technology then it May close and same challenge is with this institution (Faculty member 6). 


\section{Curriculum}

Apart from the modern technology curriculum should also be up to date to facilitate the teaching of sustainability issues

First is technology, if modern technology is attained by the institution then it will not be able to develop, second is energy because it is backbone of any development in the nation and third is curriculum for better institution you need better curriculum and it come from better development, changes and achievements and it is learnt from comparative education from other countries. Curriculum must be adopted from those countries which suit your political, geographical and social context (Faculty member 7).

\section{Faculty Competence}

The universities have less number of qualified $\mathrm{PhD}$ teachers that are a major source of research based activities:

Further, these institutions must fulfil the minimum requirements of teaching faculty as per laid down criteria of Federal Higher Education Commission and Punjab Higher Education Commission while the many of these institutions have not full time PhD faculty members (Faulty member 2).

\section{Issues}

HEIs are still facing certain issues in implementation of sustainable development programs such as issues of culture, infrastructure and link with external industrial parties (Lozano et al., 2015). It was identified that the students have no culture of research and sustainability and private sector HEIs find it difficult to attain funding form HEC,

Financing and culture of students are the major issues for sustainability of private sector higher education institution. Private Sector Higher Education Institutions have not source of funding from Higher Education Commission, Punjab Higher Education Commission and Government to meet the needs in competitive market" (Faculty member 3).

Funding issues and poor infrastructure development are also causing problem in adopting sustainable practices in private HEIs. As one respondent highlighted, This institution is facing problem of proper funding, non-availability of well infrastructure and other facilities which 
may excel the learning of students in sophisticated environment" (Faculty member 5).

Lastly, it was notified that the universities should also have links to the industrial zones to develop the practical solutions for sustainability and get them implemented in real industrial settings. It was indicated that, The lack of industrial zones and dependence upon imports increase the unemployment ratio, which result in collapse of the entire cycle of sustainability" (Faculty member 10).

Table 1 and Figure 1 indicate the frequencies of each theme that the participants talked about, the figures on the intersection of each theme and the faculty member indicate the number of times the issue was mentioned. The same is shown in graphical format in Figure 2, the colored portion in each bar indicates the relative time each theme was talked about in overall response given by that participant related to study questions.

Table 1

Matrix Coding Query

\begin{tabular}{|c|c|c|c|c|c|c|c|c|c|}
\hline & $\mathrm{A}$ & B & $\mathrm{C}$ & $\mathrm{D}$ & $E$ & $\mathrm{~F}$ & $\mathrm{G}$ & $\mathrm{H}$ & I \\
\hline & $\begin{array}{l}\text { Barriers } \\
\text { for } \\
\text { sustainable } \\
\text { develop- } \\
\text { ment }\end{array}$ & $\begin{array}{c}\text { Challenges } \\
\text { for } \\
\text { sustainable } \\
\text { developmen } \\
\mathrm{t}\end{array}$ & $\begin{array}{l}\text { Issues } \\
\text { faced } \\
\text { by } \\
\text { HEI }\end{array}$ & $\begin{array}{c}\text { Role of } \\
\text { Private HEIs } \\
\text { in sustainable } \\
\text { development }\end{array}$ & $\begin{array}{l}\text { Research } \\
\text { Culture }\end{array}$ & $\begin{array}{l}\text { Role of } \\
\text { technology } \\
\text { and } \\
\text { infrastruc- } \\
\text { ture }\end{array}$ & $\begin{array}{l}\text { Stake } \\
\text { holders } \\
\text { Role }\end{array}$ & $\begin{array}{l}\text { Sustainable } \\
\text { Develop- } \\
\text { ment }\end{array}$ & $\begin{array}{l}\text { Sustain } \\
\text { able } \\
\text { HEI }\end{array}$ \\
\hline $\begin{array}{l}\text { Faculty } \\
\text { member } 1\end{array}$ & 2 & 3 & 1 & 8 & 3 & 3 & 2 & 1 & 2 \\
\hline $\begin{array}{l}\text { Faculty } \\
\text { member } 2\end{array}$ & 3 & 3 & 1 & 8 & 2 & 3 & 2 & 1 & 3 \\
\hline $\begin{array}{l}\text { Faculty } \\
\text { member } 3\end{array}$ & 2 & 2 & 0 & 8 & 1 & 3 & 3 & 1 & 1 \\
\hline $\begin{array}{l}\text { Faculty } \\
\text { member } 4\end{array}$ & 4 & 2 & 4 & 7 & 1 & 1 & 5 & 2 & 3 \\
\hline $\begin{array}{l}\text { Faculty } \\
\text { member } 5\end{array}$ & 6 & 3 & 3 & 8 & 2 & 2 & 4 & 1 & 2 \\
\hline $\begin{array}{l}\text { Faculty } \\
\text { member } 6\end{array}$ & 2 & 4 & 1 & 7 & 2 & 3 & 2 & 1 & 1 \\
\hline $\begin{array}{l}\text { Faculty } \\
\text { member } 7\end{array}$ & 6 & 3 & 3 & 5 & 1 & 2 & 1 & 1 & 1 \\
\hline $\begin{array}{l}\text { Faculty } \\
\text { member } 8\end{array}$ & 7 & 2 & 0 & 6 & 1 & 2 & 2 & 1 & 1 \\
\hline $\begin{array}{l}\text { Faculty } \\
\text { member } 9\end{array}$ & 3 & 1 & 3 & 10 & 1 & 3 & 3 & 2 & 1 \\
\hline $\begin{array}{l}\text { Faculty } \\
\text { member } 10\end{array}$ & 7 & 0 & 1 & 10 & 1 & 2 & 4 & 1 & 1 \\
\hline $\begin{array}{l}\text { Faculty } \\
\text { member } 11\end{array}$ & 3 & 1 & 1 & 7 & 1 & 2 & 2 & 1 & 1 \\
\hline
\end{tabular}




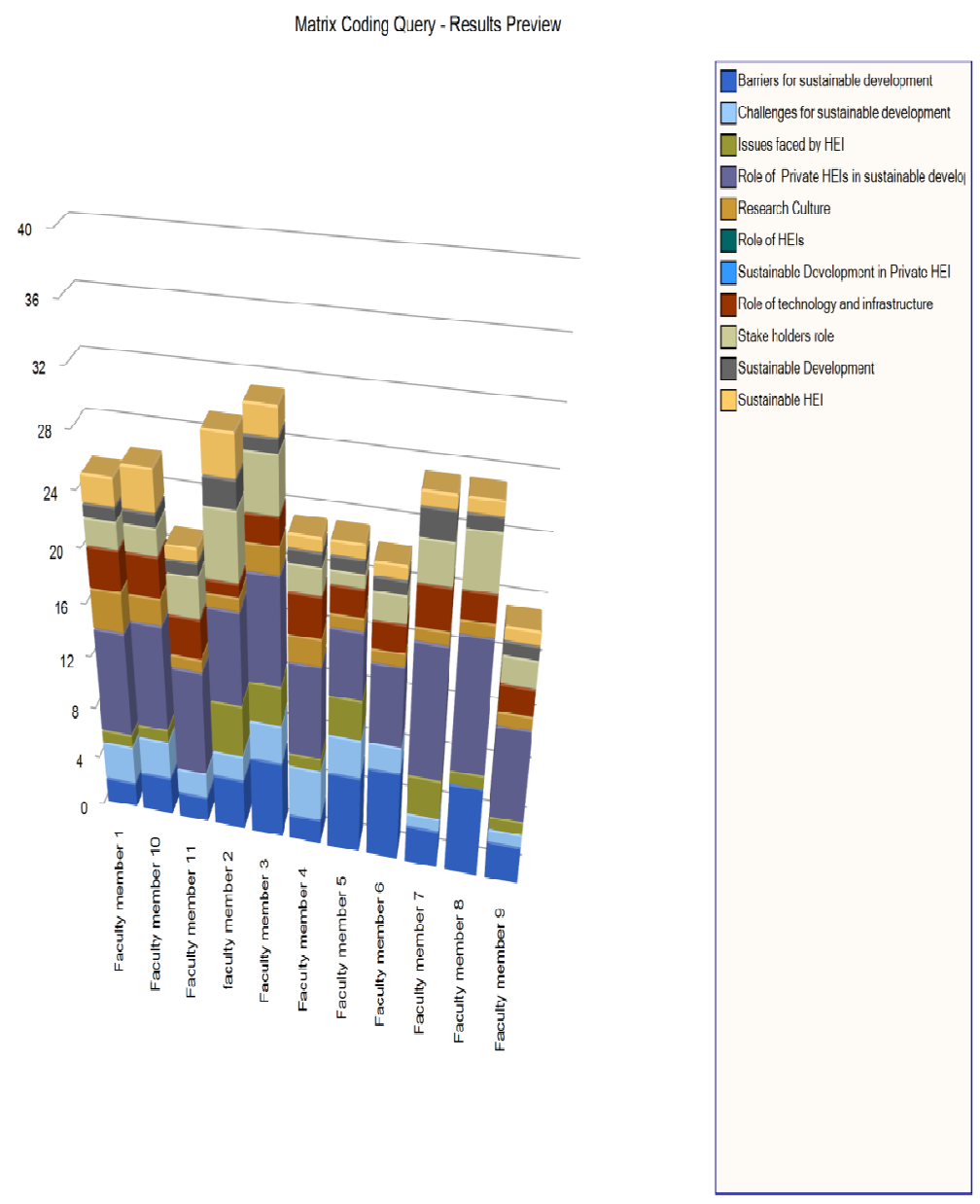

Figure 1: Bar graph of Matrix coding query results

\section{Concept Map}

The conceptual map is developed to show the relationship in themes and sub-themes (Figure 2). The barriers in HEIs regarding sustainable development include, funding, cultural issues, resistance, lack of commitment, owners' mindset, training and competency issues of faculty. 


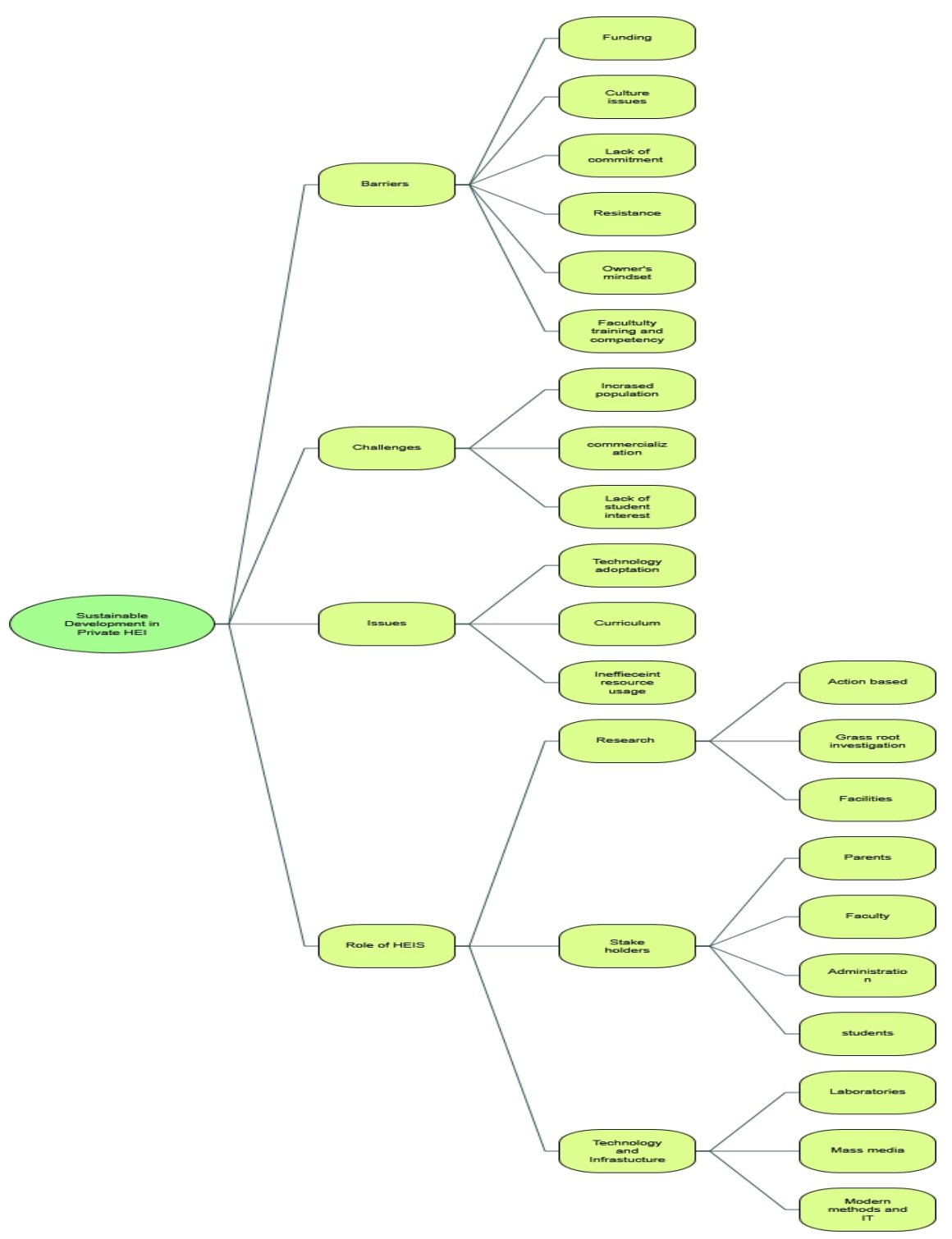

Figure 2: Concept Map 
The second theme is challenges of sustainable development include the increased population, commercialization and lack of interest among students. The main issues in sustainable development by the private sector HEIs were adoption of technology, improper curriculum and usage of resources. There are three ways in which the HEIs in private sector can contribute to promotion of sustainable development. First of all they can indulge in action research that investigates the issues on grass route level, secondly the stakeholders parents, students, faculty and administration can play their role in promotion of sustainability, and lastly the infrastructure of modern labs, mass media and IT can aid this process

\section{Conclusions and Future Perceptions}

The participants expressed different kind of views regarding the concept of sustainability. The faculty members expressed the concept of sustainability as being about keeping in view the future needs, effective resource usage, protection of resources for the next generation and efficiently managing the existing resources. In contrast to the responses about sustainable development some of the faculty members had no idea about the concept of sustainable institution. It shows that still there is lack of knowledge regarding the concept of sustainable institutions in Pakistan. While some of the participants were well aware of the concept as they said that sustainable institutions are those that play an active role in efficient resource usage, knowledge generation and education regarding the sustainable development to conserve the resources for future.

SHEIs are the institutions that have an active plan to improve the sustainability in area of health, food and climate conservation. Private HEIs constitute a greater portion of higher educational institutes in Pakistan and it imparts them the responsibility to contribute towards sustainable development. Anumber of barriers was identified by the participants that are causing a hurdle in sustainable development promotion by private sector HEIs. Lack of finance was indicated as one of the main barriers as it causes the universities to not have the required infrastructure and technologies that can be devoted to sustainable development. The students come from different backgrounds and they are mostly from backward areas and government institutes that are only interested in getting degree. They have no concern toward the research and knowledge creating activities. Most of the management is not ready to change and take the initiatives for sustainable development. Most of 
the university owners are engaged in cost minimization and they do not like to invest in changing the culture for sustainable development.

Universities do not pay adequately to the faculty members and in turn they are not motivated to engage in any positive extra-role behaviour. The institutes are not having enough opportunities to train their faculty members on the issues of sustainable development. Most of the private institutes are facing the challenge to acquire modern technology and use it in an efficient way to ensure the sustainable development. Apart from the modern technology curriculum should also be up to date to facilitate the teaching of sustainability issues. The universities have less number of qualified $\mathrm{PhD}$ teachers that are a major source of research based activities. It was identified that the students have no culture of research and sustainability and private sector HEIs find it difficult to attain funding from HEC. Funding issues and poor infrastructure development are also causing problem in adopting sustainable practices in private HEIs. Lastly, it was notified that the universities should also have links to the industrial zones to develop the practical solutions for sustainability and get them implemented in real industrial settings.

In general, all the participants agreed that private HEIs are the knowledge creating institutes and they can actively promote the sustainable development in Pakistan through faculty training and active involvement of all the stakeholders. This will allow them to generate the innovative solutions for sustainable development. The resources must be used in an optimal manner and development of effective curriculum that teaches the students regarding sustainability. The right technology and infrastructure can allow the private sector HEIs to play the role in sustainable development. Furthermore, the HEIs should create right class room environment, implement the social and mass media usage, IT should be rightly incorporated, the modern technology should be used and laboratories should be equipped with modern facilities.

The right focus should be on solution based advanced research tools and equipment's can also help to generate ideas for efficient use of energy and environmental conservation. Research about the methods of developing sustainability and taking the practical issues is one of the major contributions by the private sector HEIs. This was indicated by the participants that the research must be action oriented, based on local issues, that focuses on the grass root level investigation and in this regard the public and private sector partnership could also be fruitful

Loyalty, commitment and support from the faculty and the combined collaboration and cooperation by all the stakeholders (Leaders, students, 
administrative staff and external stakeholders) are needed to develop sustainable HEIs

The major limitation of this research is that the results of this research cannot be generalized to all the private sector universities/institutes because only four DAIs were taken to conduct this study. This study can be done in the larger context of all private sector HEIs operating in Punjab province through quantitative or mixed method inquiry. Future study can be done with considering of sample from public as well as private sector HEIs. The results of this research can also be compared to other countries. The practices that are undertaken to ensure sustainable development in developed nation's HEIs can also be taken to Pakistani context to check their applicability. 


\section{References}

A. Adams, C. (2013). Sustainability Reporting and Performance Management in Universities: Challenges and Benefits. Sustainability Accounting, Management and Policy Journal, 4(3), 384-392.

Amaral, L. P., Martins, N., \& Gouveia, J. B. (2015). Quest for a Sustainable University: a Review. International Journal of Sustainability in Higher Education, 16(2), 155-172.

Barth, M. (2013). Many roads lead to sustainability: a process-oriented analysis of change in higher education. International Journal of Sustainability in Higher Education, 14(2), 160-175.

Braun, V., \& Clarke, V. (2006). Using Thematic Analysis in Psychology. Qualitative Research in Psychology, 3(2), 77-101.

Bryman, A. (2016). Social Research Methods. Oxford University Press.

Christie, B. A., Miller, K. K., Cooke, R., \& White, J. G. (2015). Environmental Sustainability in Higher Education: What do Academics Think?. Environmental Education Research, 21(5), 655-686.

Clugston, R. M., \& Calder, W. (1999). Critical Dimensions of Sustainability in Higher Education. Sustainability and University Life, 5(1), 31-46.

Davis, G., O'callaghan, F., \& Knox, K. (2009). Sustainable Attitudes and Behaviours Amongst a Sample of Non-academic Staff: A Case Study from an Information Services Department, Griffith University, Brisbane. International Journal of Sustainability in Higher Education, 10(2), 136-151.

Dempsey, N., Bramley, G., Power, S., \& Brown, C. (2011). The Social Dimension of Sustainable Development: Defining Urban Social Sustainability. Sustainable Development, 19(5), 289-300.

Elliott, H., \& Wright, T. (2013, November). Barriers to Sustainable Universities and Ways Forward: A Canadian Students' Perspective. In 3rd World Sustainability Forum. 
Figueredo, F. R., \&Tsarenko, Y. (2013). Is “Being Green" a Determinant of Participation in University Sustainability Initiatives?. International Journal of Sustainability in Higher Education, 14(3), 242-253.

Halldórsdóttir, S., Fridlund, B., \& Hildingh, C. (2000). Qualitative Research Methods in the Service of Health.

Godemann, J., Bebbington, J., Herzig, C., \& Moon, J. (2014). Higher Education and Sustainable Development: Exploring Possibilities for Organisational Change. Accounting, Auditing \& Accountability Journal, 27(2), 218-233.

Jedege, O. (2016). The Role of Private Higher Education in Sustainable Development. National Open University of Nigeria

Jorge, M. L., Madueño, J. H., Cejas, M. Y. C., \& Peña, F. J. A. (2015). An Approach to the Implementation of Sustainability Practices in Spanish Universities. Journal of Cleaner Production, 106, 34-44.

Kościelniak, C. (2014). A Consideration of the Changing Focus on the Sustainable Development in Higher Education in Poland. Journal of Cleaner Production, 62, 114-119.

Lozano, R. (2008). Envisioning Sustainability Three-Dimensionally. Journal of Cleaner Production, 16(17), 1838-1846.

Lozano, R., Ceulemans, K., Alonso-Almeida, M., Huisingh, D., Lozano, F. J., Waas, T., \& Hugé, J. (2015). A Review of Commitment and Implementation of Sustainable Development in Higher Education: Results from a Worldwide Survey. Journal of Cleaner Production, 108, 1-18.

Lozano, R., Lukman, R., Lozano, F. J., Huisingh, D., \& Lambrechts, W. (2013). Declarations for Sustainability in Higher Education: Becoming Better Leaders, Through Addressing the University System. Journal of Cleaner Production, 48, 10-19.

Mader, C., Scott, G., \& Abdul Razak, D. (2013). Effective Change Management, Governance and Policy for Sustainability Transformation in Higher Education. Sustainability Accounting, Management and Policy Journal, 4(3), 264-284. 
Milutinović, S., \& Nikolić, V. (2014). Rethinking Higher Education for Sustainable Development in Serbia: An Assessment of Copernicus Charter Principles in Current Higher Education Practices. Journal of Cleaner Production, 62, 107-113.

Mughal, S. H., Qaisrani, N., Solangi, G., \&Faiz, S. (2011). Promoting Education for Sustainable Development: Challenges and Issues for Higher Education Institutions in Pakistan. International Journal of Learning \& Development, 1(1), 159-165.

Punch, K. F. (2013). Introduction to Social Research: Quantitative and Qualitative Approaches. sage.

Sabir, M. (2008). The Role of Universities in Sustainable Development with Special Focus on Pakistan.

Silverman, D. (2013). Doing Qualitative Research: A Practical Handbook. SAGE Publications Limited.

Sammalisto, K., Sundström, A., \& Holm, T. (2015). Implementation of Sustainability in Universities as Perceived by Faculty and Staff-a Model from a Swedish University. Journal of Cleaner Production, 106, 45-54.

Sandelowski, M. (1995). Sample size in Qualitative Research. Research in Nursing \& Health, 18(2), 179-183.

Shriberg, M., \& Harris, K. (2012). Building Sustainability Change Management and Leadership Skills in Students: Lessons Learned from "Sustainability and the Campus" at the University of Michigan. Journal of Environmental Studies and Sciences, 2(2), 154-164.

Sibbel, A. (2009). Pathways Towards Sustainability Through Higher Education. International Journal of Sustainability in Higher Education, 10(1), 68-82.

Stephens, J. C., Hernandez, M. E., Román, M., Graham, A. C., \& Scholz, R. W. (2008). Higher Education as a Change Agent for Sustainability in Different Cultures and Contexts. International Journal of Sustainability in Higher Education, 9(3), 317-338. 
Tapia-Fonllem, C., Fraijo-Sing, B., Corral-Verdugo, V., \& Ortiz Valdez, A. (2017). Education for Sustainable Development in Higher Education Institutions: It's Influence on the Pro-Sustainability Orientation of Mexican Students. SAGE Open, 7(1),1-15 2158244016676295.

Velazquez, L., Munguia, N., \& Sanchez, M. (2005). Deterring Sustainability in Higher Education Institutions: An Appraisal of the Factors which Influence Sustainability in Higher Education Institutions. International Journal of Sustainability in Higher Education, 6(4), 383-391.

Velazquez, L., Munguia, N., \& Sanchez, M. (2005). Deterring Sustainability in Higher Education Institutions: An Appraisal of the Factors which Influence Sustainability in Higher Education Institutions. International Journal of Sustainability in Higher Education, 6(4), 383-391.

Verhulst, E., \& Lambrechts, W. (2015). Fostering the Incorporation of Sustainable Development in Higher Education. Lessons Learned from a Change Management Perspective. Journal of Cleaner Production, 106, 189-204.

Waas, T., Hugé, J., Verbruggen, A., \& Wright, T. (2011). Sustainable Development: A Bird's eye View. Sustainability, 3(10), 1637-1661.

Weber, L., \& Duderstadt, J. J. (Eds.). (2012). Global Sustainability and the Responsibilities of Universities. Economica.

Wright, T. S. A. (2006). Giving "Teeth" to an Environmental Policy: a Delphi study at Dalhousie University. Journal of Cleaner Production, 14(9-11), 761-768.

Wright, T. S., \& Wilton, H. (2012). Facilities Management Directors' Conceptualizations of Sustainability in Higher Education. Journal of Cleaner Production, 31, 118-125.

Wright, T., \& Horst, N. (2013). Exploring the Ambiguity: What Faculty Leaders Really think of Sustainability in Higher Education. International Journal of Sustainability in Higher Education, 14(2), 209-227. 
Yarime, M., Trencher, G., Mino, T., Scholz, R. W., Olsson, L., Ness, B., ... \& Rotmans, J. (2012). Establishing Sustainability Science in Higher Education Institutions: Towards an Integration of Academic Development, Institutionalization, and Stakeholder Collaborations. Sustainability Science, 7(1), 101-113.

Zahid, M. (2018) Sustainable Development and our varisties. Retrieved from:https://dailytimes.com.pk/172165/sustainable-developmentvaristies/

Zeegers, Y., \& Francis Clark, I. (2014). Students' Perceptions of Education for Sustainable Development. International Journal of Sustainability in Higher Education, 15(2), 242-253.

\section{Citation of this Article:}

Waqas, M., Rehman, M., \& Rehman, A. (2019). The barriers and challenges faced by private sector higher education institutions (HEIs) in promoting sustainable development: A qualitative inquiry in Pakistan.Pakistan Journal of Education, 36(1), 19-46. 